\title{
DATING CHARRED SOIL ORGANIC MATTER: COMPARISON OF RADIOCARBON AGES FROM MACROCHARCOALS AND CHEMICALLY SEPARATED CHARCOAL CARBON
}

\author{
Eileen Eckmeier ${ }^{1,2} \bullet$ Klaas van der Borg $^{3} \bullet$ Ursula Tegtmeier $^{4} \bullet$ Michael W I Schmidt $^{1} \bullet$ \\ Renate Gerlach ${ }^{5}$
}

\begin{abstract}
Radiocarbon dating of charcoal in soils is commonly used to reconstruct past environmental processes. Also microcharcoal that is chemically isolated from soil organic matter by high-energy UV photo-oxidation can be dated with ${ }^{14} \mathrm{C}$ accelerator mass spectrometry (AMS). We compared the ${ }^{14} \mathrm{C}$ AMS ages of 13 pairs of hand-picked macrocharcoals and microcharcoal samples separated via the UV oxidation method; both charcoal fractions were taken from the same soil samples (prehistoric pit fillings). We found that in most cases, the microcharcoal fraction yielded older ages than the single macrocharcoal pieces, and that the differences between the ages are not systematic. A reason for these age differences might be that the microcharcoal fraction consists of more stable components than macrocharcoals and thus yields older ages. Dating of microcharcoal would give a mean age of charred organic matter in soil material and the ages of the more stable compounds. Thus, ${ }^{14} \mathrm{C}$ data obtained from the microcharcoal fraction in soils is not comparable to macrocharcoal ages and should not be used to complement existing macrocharcoal data sets.
\end{abstract}

\section{INTRODUCTION}

Charred organic matter is ubiquitously present in soils and sediments (cf. Forbes et al. 2006), and charcoal, or chemically isolated charcoal carbon, is commonly used as a marker for paleofire events (Bird and Cali 1998). Radiocarbon dating of macroscopically visible charcoal particles (macrocharcoal) in sediments or soils allows the reconstruction of past environmental processes like fires, vegetation changes, or pedological processes (Carcaillet et al. 2002, 2006; Willis and van Andel 2004; Wang et al. 2005; Hajdas et al. 2007), and it is commonly used to determine the age of archaeological findings (e.g. Liedgren et al. 2007). A recent approach is to determine the ages of soil microcharcoal, which, in contrast to macrocharcoal, could also derive from grass fires. Microcharcoal, i.e. the charcoal fraction that is not macroscopically visible, can be chemically separated from the more labile soil organic matter by high-energy UV photo-oxidation that was found to isolate the stable and older carbon components. Resulting microcharcoal samples can be subsequently dated with ${ }^{14} \mathrm{C}$ accelerator mass spectrometry (AMS) (Skjemstad et al. 1996, 1999).

A prerequisite for using charcoal in paleoecological or archaeological research is that charcoal is highly resistant to decomposition due to its condensed aromatic structures, the reason why it is present in soils over millennia. Recent studies, however, showed that charcoal is prone to surface oxidation and degradation either by abiotic processes (Cheng et al. 2006) or biological activity (Hamer et al. 2004; Hockaday et al. 2007), and that it changes its chemical and physical structure during decomposition over time in oxic environments like soils (Cohen-Ofri et al. 2006). The heterogeneous structure of charcoal has an influence on its susceptibility to oxidation, so that charcoal could consist of compounds that have different ages (Krull et al. 2006). As a result, microcharcoal samples that result from the breakdown of larger fragments could differ in their chemical composition and yield different ${ }^{14} \mathrm{C}$ ages than macrocharcoal samples.

\footnotetext{
${ }^{1}$ University of Zurich, Dept. of Geography, Winterthurerstrasse 190, 8057 Zurich, Switzerland.

${ }^{2}$ Also at Weizmann Institute of Science, Kimmel Center of Archaeological Science, Rehovot 76100, Israel. Corresponding author. Email: eileen.eckmeier@geo.uzh.ch.

${ }^{3}$ Universiteit Utrecht, Faculteit Natuur- en Sterrenkunde, 3508 TA Utrecht, the Netherlands.

${ }^{4}$ University of Cologne, Dept. for Pre- and Protohistory, Archaeobotany Laboratory, Weyertal 125, 50923 Köln, Germany.

${ }^{5}$ Rheinisches Amt für Bodendenkmalpflege, Endenicher Strasse 133, 53115 Bonn, Germany.
} 
Dating of chemically isolated microcharcoal might provide information when macroscopic charcoal is absent in the soil record. This would allow to increase the number of dates for archaeological sites or to date fire events that left only small charcoal particles behind. In this study, we dated charred organic matter taken from fossil soil material (relic Anthrosols and Neolithic settlement pit fillings) in the Lower Rhine Basin (NW Germany; Gerlach et al. 2006). To elucidate if the dating of chemically isolated microcharcoal could indeed substitute the dating of soil macrocharcoal particles, we compared ${ }^{14} \mathrm{C}$ ages of single macrocharcoal particles with those of microcharcoal samples; both charcoal fractions were separated from the same soil sample.

\section{MATERIAL AND METHODS}

Bulk soil samples ( 2 kg) were taken from the humic fossil soil material of relic Anthrosols in the Lower Rhine Basin (NW Germany). The fossil soil horizons were always connected with man-made pits. These pits were filled with the same dark soil material, i.e. ancient top-soil material, that contained no artifacts but a few macrocharcoals (Gerlach et al. 2006). The horizons and pits were either situated directly under the recent top-soil or they were covered by colluvial sediment. Samples were taken from pit fillings and soil horizons. Additionally, 3 settlement pits and 1 grave from clearly defined Early Neolithic (5500-5000 BC) settlement areas were sampled.

After drying the soil samples at $40{ }^{\circ} \mathrm{C}$, all visible macrocharcoal particles ( $\left.>1 \mathrm{~mm}\right)$ were manually selected from the bulk soil samples for identification of wood species in order to take, if possible, charcoal of short-lived tree species or short-lived parts of trees (i.e. twigs) for ${ }^{14} \mathrm{C}$ dating. Soil aggregates were crushed subsequently, and coarse material $(>2 \mathrm{~mm}$ ) was removed by dry sieving.

Microcharcoal was isolated from the less stable total soil organic matter via high-energy UV photooxidation as described by Skjemstad et al. $(1993,1999)$. The soil samples (particle size fraction $<53$ $\mu \mathrm{m}$ ) were treated with high-energy UV light for $2 \mathrm{hr}$ to destroy the more labile soil organic matter. The proportion of charcoal carbon that was left in the soil sample after the oxidation treatment was estimated after the identification of carbon compounds via ${ }^{13} \mathrm{C}$ NMR (CP/MAS) by using the aryl fraction that has been corrected for lignin or lignin-like structures.

We dated 13 single macrocharcoal particles and 13 microcharcoal samples, 1 of each derived from the same soil sample. The material was treated according to the laboratory protocols and subsequently dated by AMS (Universities of Kiel and Utrecht). The comparisons between the results for both charcoal fractions samples were made using uncalibrated ${ }^{14} \mathrm{C}$ ages.

\section{RESULTS}

Macrocharcoal particles had been distributed homogeneously in the soil material. The following wood species could be identified: Quercus (oak), Fraxinus (ash), Ulmus (elm), Corylus (hazel), Pomoideae (pomaceous fruit trees), and deciduous wood species that were not further indentifiable.

Microcharcoal carbon (C) was found in all samples subjected to the photo-oxidation treatment, with proportions between 190 to $650 \mathrm{~g}$ charcoal $\mathrm{C} \mathrm{kg}^{-1}$ soil organic carbon. The highest yields were measured in the settlement pit fillings and the grave material, in which half of the organic matter is charred material (average $523 \mathrm{~g} \mathrm{~kg}^{-1}$ ), while in Anthrosol soil material an average of one-third of soil organic carbon was charcoal carbon (average $317 \mathrm{~g} \mathrm{~kg}^{-1}$ ).

The AMS ${ }^{14} \mathrm{C}$ ages of both macro- and microcharcoal, as shown in Table 1 and Figure 1, ranged between $10,460 \pm 90$ to $1021 \pm 39 \mathrm{BP}$; the macrocharcoals yielded ages from $8340 \pm 80$ to $1021 \pm$ $39 \mathrm{BP}$, the microcharcoals from $10,460 \pm 90$ to $3454 \pm 35 \mathrm{BP}$. When comparing the macro- and 
microcharcoal ages from the same soil sample, most microcharcoal samples (9 of 13) had older ages than the corresponding macrocharcoals, although the differences were not significant $(p=0.133)$ and the ages of macro- and microcharcoal did not correlate $(r=0.578)$. The average difference in age between macro- and microcharcoals was $916 \mathrm{yr}$. If the sample pair that gave the largest difference were to be omitted (SE 58), the average difference would be reduced to $530 \mathrm{yr}$.

Table 1 Description of charcoal samples and dated ${ }^{14} \mathrm{C}$ ages of macrocharcoal particles $(>1 \mathrm{~mm})$ and microcharcoal chemically separated from labile soil organic matter by UV photo-oxidation. Both fractions were taken from the same soil samples. ${ }^{14} \mathrm{C}$ ages are given in uncalibrated yr BP.

\begin{tabular}{|c|c|c|c|c|c|c|c|c|c|}
\hline \multirow[b]{2}{*}{$\begin{array}{l}\text { Sample } \\
\text { nr }\end{array}$} & \multirow[b]{2}{*}{ Type $^{\mathrm{a}}$} & \multicolumn{4}{|c|}{ Macrocharcoal } & \multicolumn{4}{|c|}{ Microcharcoal } \\
\hline & & Lab code & $\begin{array}{l}\text { Wood } \\
\text { species }\end{array}$ & $\begin{array}{l}\delta^{13} \mathrm{C} \\
(\% o)\end{array}$ & $\begin{array}{l}\delta^{14} \mathrm{C} \text { age } \\
(\mathrm{BP})\end{array}$ & Lab code & $\begin{array}{l}\text { Char C } \\
\mathrm{g} \mathrm{kg}^{-1} \\
\text { SOC }\end{array}$ & $\begin{array}{l}\delta^{13} \mathrm{C} \\
(\% o)\end{array}$ & $\begin{array}{l}{ }^{14} \mathrm{C} \text { age } \\
(\mathrm{BP})\end{array}$ \\
\hline 42 & Horizon & UtC-11209 & Deciduous & -26.4 & $8340 \pm 80$ & UtC-14882 & 290 & -26.1 & $7443 \pm 49$ \\
\hline 16 & Pit (off) & UtC-11208 & n.d. & -27.0 & $8320 \pm 140$ & UtC-14879 & 380 & -26.1 & $8120 \pm 60$ \\
\hline 19 & Pit (on) & UtC-11204 & Pomoideae & -25.9 & $6212 \pm 44$ & UtC-14417 & 650 & -24.5 & $6260 \pm 80$ \\
\hline 23 & Pit (on) & UtC-11199 & Fraxinus & -24.7 & $6210 \pm 50$ & UtC-14418 & 500 & -27.7 & $8690 \pm 80$ \\
\hline 57 & Pit (on) & UtC-11200 & Fraxinus & -28.1 & $6180 \pm 60$ & UtC-14420 & 470 & -26.9 & $6760 \pm 80$ \\
\hline 25 & Pit (off) & UtC-11205 & Ulmus & -23.2 & $6161 \pm 47$ & UtC-14880 & 250 & -25.5 & $6031 \pm 46$ \\
\hline 17 & Grave & UtC-11206 & Corylus & -24.9 & $6158 \pm 50$ & UtC-14416 & 470 & -25.1 & $6300 \pm 80$ \\
\hline 5 & Pit (off) & KIA-10696 & Pomoidae & -25.1 & $5230 \pm 35$ & UtC-14878 & 400 & -25.3 & $5390 \pm 60$ \\
\hline 58 & Pit (off) & UtC-11203 & Pomoidae & -26.6 & $4920 \pm 60$ & UtC-14421 & 250 & -29.9 & $10,460 \pm 90$ \\
\hline 69 & Pit (off) & KIA-10693 & Quercus & -26.2 & $4615 \pm 35$ & UtC-11403 & 330 & -25.5 & $3797 \pm 34$ \\
\hline 34 & Pit (off) & UtC-11201 & Quercus & -25.6 & $4190 \pm 50$ & UtC-14881 & 190 & -26.0 & $5469 \pm 46$ \\
\hline 70 & Pit (off) & KIA-10697 & Quercus & -24.2 & $2985 \pm 30$ & UtC-11404 & 260 & -25.1 & $3454 \pm 35$ \\
\hline 59 & Pit (off) & UtC-11202 & Quercus & -24.7 & $1021 \pm 39$ & UtC-14883 & 500 & -25.1 & $4270 \pm 40$ \\
\hline
\end{tabular}

${ }^{\mathrm{a}}$ Horizon = relic Anthrosol horizon; Pit (off) = pit filling off-site; Pit (on) = pit filling on-site (Early Neolithic settlement areas).

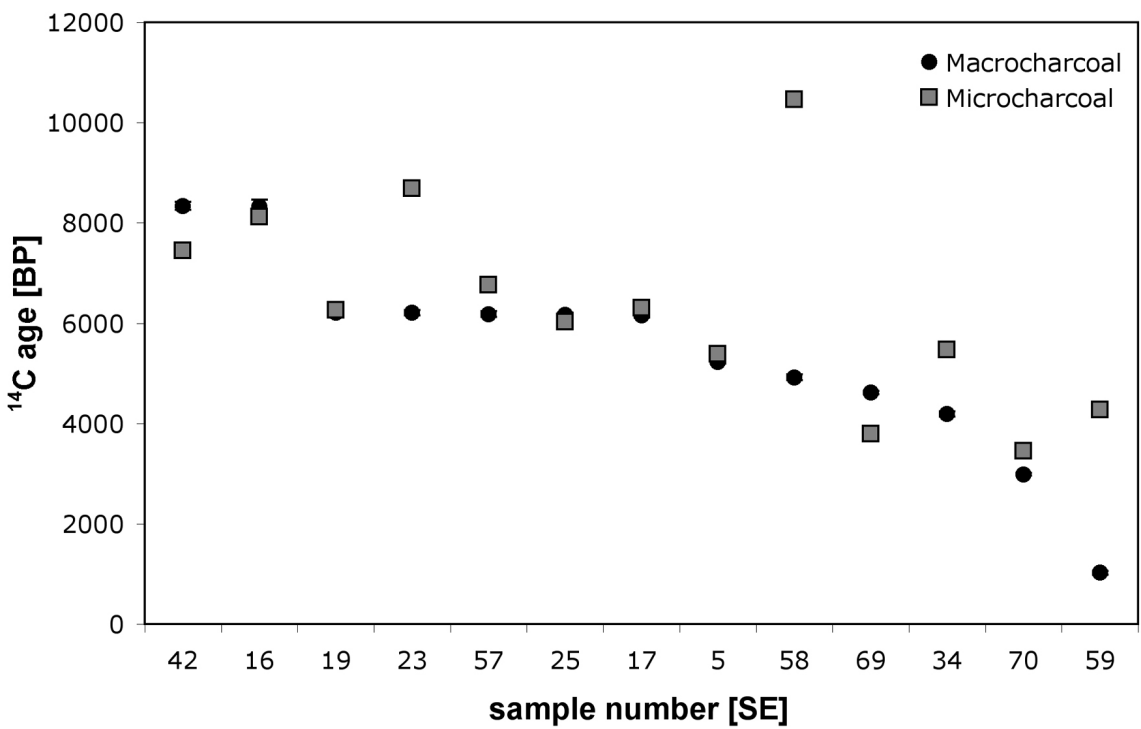

Figure 1 Uncalibrated ${ }^{14} \mathrm{C}$ ages (BP) of macrocharcoal particles $(>1 \mathrm{~mm})$ and microcharcoal chemically separated from labile soil organic matter by UV photo-oxidation. Both charcoal samples were taken from the same soil sample. The error bars are too small to be shown. 


\section{DISCUSSION}

The differences in ${ }^{14} \mathrm{C}$ ages obtained for the sample pairs of macro- and microcharcoal were not systematic; they varied from 48 to $5540 \mathrm{yr}$. The corresponding samples taken from the grave filling showed an offset of $142 \mathrm{yr}$, although the charred material and the soil were put into the grave pit together.

The disparities in the obtained ages could have several reasons. In general, soil organic matter, including charred organic matter, consists of a conglomerate of organic materials with different turnover times and, therefore, in different stages of decomposition (Scharpenseel and BeckerHeidmann 1992). Different fractions of soil organic matter should yield different ${ }^{14} \mathrm{C}$ ages, and the most stable carbon component must not necessarily be the oldest (Krull et al. 2006). Still, charcoal carbon, or black carbon which is a constituent of charcoal and consists mainly of recalcitrant aromatic carbon structures, usually yields the older ages. As examples, Schmidt et al. (2002) reported that in 3 of 4 dated samples, the black carbon fraction was older than the total soil organic carbon. Pessenda et al. (2001) showed that the ${ }^{14} \mathrm{C}$ ages of soil organic matter were always significantly younger than the ages of the humin fractions, but the ages of the humin fractions agreed well with macrocharcoal ages. Kristiansen et al. (2003) ${ }^{14} \mathrm{C}$ dated chemical soil organic matter fractions and reported different age patterns. In 1 sample, the difference between charcoal and humic acid ages reached nearly $2000 \mathrm{yr}$, and some charcoal samples yielder younger ages than the humic acids.

Charcoal consists of various chemical compounds and is very heterogeneous. It was shown that charcoal compounds undergo initial surface oxidation, which makes them susceptible to decomposition. If microbial degradation of charcoal is quantitatively important (Baldock and Smernik 2002; Hamer et al. 2004; Hockaday et al. 2007) or not (Cheng et al. 2006; Bruun et al. 2008) is still under discussion. The resistance against biological or chemical decomposition is determined by the combustion conditions (Baldock and Smernik 2002) and depends on the elemental composition or chemical recalcitrance of the charcoal components, while organo-mineral associations seem to stabilize carbon only over decadal timescales (Krull et al. 2006). Older charcoal, compared to recently charred material, became more functionalized and degraded over time. Cohen-Ofri et al. (2006) used a variety of spectroscopic analyses to show that the graphitic component of charcoal oxidizes into material resembling humic acids. They confirm the findings of Bird et al. (2002), who described the degraded internal structures of fossil charcoal. Products of charcoal carbon decompositioncondensed aromatic rings-were identified in dissolved organic matter of charcoal leachates and soil pore water (Hockaday et al. 2006).

It can be presumed that the more labile compounds of soil charcoals degrade over time, while more stable carbon moieties would be preferentially enriched. The labile charcoal compounds would be destroyed during photo-oxidation, while the macrocharcoal particles might still contain the labile compounds, as well as adsorbed dissolved organic matter, which can attract microbes into the pores of charcoal (Pietikäinen et al. 2000). A contamination with organic substances that could be present in the charcoal particles also after acid-alkali-acid (AAA) treatment might bias the yielded ${ }^{14} \mathrm{C}$ ages, too (Alon et al. 2002).

The age of a charcoal does not date a fire event, but the death of the charred plant. This inbuilt age, i.e. the time delay between death and charring, could be several centuries (e.g. between 30 and 610 $\mathrm{yr}$ in coastal temperate rainforest of British Columbia, Canada). Consequently, the ${ }^{14} \mathrm{C}$ ages of wood charcoal would overestimate the date of burning and thus give the maximum ages of fire events (Gavin 2001). Dating a pool of macrocharcoal particles delivers a mean age of charcoal assem- 
blages, which would be a representative age of the burning event. However, Gavin et al. (2003) reported that $1{ }^{14} \mathrm{C}$ date per site was sufficient to identify the time since the last fire.

Another critical point is that the fate of charcoal after its production is not yet well known. Charcoal produced during a single fire event is not necessarily found in the same soil horizon. Charcoal particles in soils could undergo translocation via erosion (e.g. Carcaillet et al. 2006) and bioturbation through soil-mixing fauna (Carcaillet 2001; Topoliantz and Ponge 2003; Eckmeier et al. 2007), roots (Zackrisson et al. 1996), or freeze-thaw processes (Carcaillet and Talon 1996). The investigated soils have been influenced by external factors over millennia, and unknown processes and events might have influenced the age distribution as well.

In summary, the observed differences between the ages of macro- and microcharcoal samples could be explained mainly by the following: (i) The microcharcoal fraction might contain the products of charcoal degradation. As a result, the microcharcoal fraction would contain more stable, and thus rather older components than the macrocharcoal particles. (ii) A single macrocharcoal particle would date a single event in time. The microcharcoal sample may yield a mean age from a mixture of different biomass compounds and different char from various fire events, all with different ${ }^{14} \mathrm{C}$ ages. (iii) The UV photo-oxidation might destroy the more labile compounds present in the microcharcoal fraction, while these compounds might still be attached to macrocharcoal particles prior to ${ }^{14} \mathrm{C}$ dating.

\section{CONCLUSIONS}

We determined the ${ }^{14} \mathrm{C}$ AMS ages of 13 pairs of macro- and microcharcoal taken from the same soil samples to investigate how results from both fractions compare. We found that in most cases, the microcharcoal fraction yields older ages than single macrocharcoal pieces, and that the differences in ages between both fractions do not show any correlation.

We concluded that in soils (i) the microcharcoal fraction might consist of more stable components than macrocharcoal and thus yields more conservative ${ }^{14} \mathrm{C}$ dates, and that (ii) chemically separated microcharcoal could be used for dating when macrocharcoal is absent. Data from both charcoal fractions is, however, not comparable and microcharcoal ages should not complement existing chronologies based on macrocharcoal data. It has to be considered that the dating of microcharcoal would give a mean age of charred organic material present in a soil sample, and that the ages would derive from compounds that might be more resistant against decomposition. As a result, the ages of both fractions are not comparable because different organic compounds are examined.

\section{ACKNOWLEDGMENTS}

We wish to thank Jan O Skjemstad (CSIRO Land and Water, Australia) and his team for helping with separation and analysis of the microcharcoal samples, and for giving E Eckmeier the possibility to work in their lab. E Eckmeier was funded by the University of Zurich (Forschungskredit Nr. 57061002) and the European Association of Organic Geochemistry (Schlumberger Award). We gratefully appreciate the constructive comments of Judit Becze-Deák, Irka Hajdas, and an anonymous reviewer that helped us to improve the manuscript.

\section{REFERENCES}

Alon D, Mintz G, Cohen I, Weiner S, Boaretto E. 2002.

The use of Raman spectroscopy to monitor the removal of humic substances from charcoal: quality control for ${ }^{14} \mathrm{C}$ dating of charcoal. Radiocarbon 44(1):1-11.
Baldock JA, Smernik RJ. 2002. Chemical composition and bioavailability of thermally altered Pinus resinosa (Red pine) wood. Organic Geochemistry 33(9):1093109. 
Bird MI, Cali JA. 1998. A million-year record of fire in sub-Saharan Africa. Nature 394(6695):767-9.

Bird MI, Turney CSM, Fifield LK, Jones R, Ayliffe LK, Palmer A, Cresswell R, Robertson S. 2002. Radiocarbon analysis of the early archaeological site of Nauwalabila I, Arnhem Land, Australia: implications for sample suitability and stratigraphic integrity. Quaternary Science Reviews 21(8-9):1061-75.

Bruun S, Jensen ES, Jensen LS. 2008. Microbial mineralization and assimilation of black carbon: dependency on degree of thermal alteration. Organic Geochemistry 39(7):839-45.

Carcaillet C. 2001. Are Holocene wood-charcoal fragments stratified in alpine and subalpine soils? Evidence from the Alps based on AMS ${ }^{14} \mathrm{C}$ dates. $\mathrm{Ho}$ locene 11(2):231-42.

Carcaillet C, Almquist H, Asnong H, Bradshaw RHW, Carrión JS, Gaillard MJ, Gajewski K, Haas JN, Haberle SG, Hadorn P, Müller SD, Richard PJH, Richoz I, Rösch M, Sánchez Goñi MFS, von Stedingk H, Stevenson AC, Talon B, Tardy C, Tinner W, Tryterud E, Wick L, Willis KJ. 2002. Holocene biomass burning and global dynamics of the carbon cycle. Chemosphere 49(8):845-63.

Carcaillet C, Richard PJH, Asnong H, Capece L, Bergeron Y. 2006. Fire and soil erosion history in East Canadian boreal and temperate forests. Quaternary Science Reviews 25(13-14):1489-500.

Carcaillet C, Talon B. 1996. A view of the wood charcoal stratigraphy and dating in soil: a case study of some soils from the French Alps. Geographie Physique et Quaternaire 50:233-44.

Cheng C-H, Lehmann J, Thies JE, Burton SD, Engelhard MH. 2006. Oxidation of black carbon by biotic and abiotic processes. Organic Geochemistry 37(11): $1477-88$.

Cohen-Ofri I, Weiner L, Boaretto E, Mintz G, Weiner S. 2006. Modern and fossil charcoal: aspects of structure and diagenesis. Journal of Archaeological Science 33(3):428-39.

Eckmeier E, Gerlach R, Skjemstad JO, Ehrmann O, Schmidt MWI. 2007. Minor changes in soil organic carbon and charcoal concentrations detected in a temperate deciduous forest a year after an experimental slash-and-burn. Biogeosciences 4:377-83.

Forbes MS, Raison RJ, Skjemstad JO. 2006. Formation, transformation and transport of black carbon (charcoal) in terrestrial and aquatic ecosystems. Science of the Total Environment 370(1):190-206.

Gavin DG. 2001. Estimation of inbuilt age in radiocarbon ages of soil charcoal for fire history studies. Radiocarbon 43(1):27-44.

Gavin DG, Brubaker LB, Lertzman KP. 2003. Holocene fire history of a coastal temperate rain forest based on soil charcoal radiocarbon dates. Ecology 84(1):186201.

Gerlach R, Baumewerd-Schmidt H, van den Borg K, Eckmeier E, Schmidt MWI. 2006. Prehistoric alter- ation of soil in the Lower Rhine Basin, northwest Germany-archaeological, ${ }^{14} \mathrm{C}$ and geochemical evidence. Geoderma 136(1):38-50.

Hajdas I, Schlumpf N, Minikus-Stary N, Hagedorn F, Eckmeier E, Schoch W, Burga C, Bonani G, Schmidt MWI, Cherubini P. 2007. Radiocarbon ages of soil charcoals from the southern Alps, Ticino, Switzerland. Nuclear Instruments and Methods in Physics Research B 259(1):398-402.

Hamer U, Marschner B, Brodowski S, Amelung W. 2004. Interactive priming of black carbon and glucose mineralisation. Organic Geochemistry 35(7):823-30.

Hockaday WC, Grannas AM, Kim S, Hatcher PG. 2006. Direct molecular evidence for the degradation and mobility of black carbon in soils from ultrahigh-resolution mass spectral analysis of dissolved organic matter from a fire-impacted forest soil. Organic Geochemistry 37(4):501-10.

Hockaday WC, Grannas AM, Kim S, Hatcher PG. 2007. The transformation and mobility of charcoal in a fireimpacted watershed. Geochimica et Cosmochimica Acta 71(14):3432-45.

Kristiansen SM, Dalsgaard K, Holst MK, Aaby B, Heinemeier J. 2003. Dating of prehistoric burial mounds by ${ }^{14} \mathrm{C}$ analysis of soil organic matter fractions. Radiocarbon 45(1):101-12.

Krull ES, Swanston CW, Skjemstad JO, McGowan JA. 2006. Importance of charcoal in determining the age and chemistry of organic carbon in surface soils. Journal of Geophysical Research-Biogeosciences 111: G04001, doi: 10.1029/2006JG000194.

Liedgren LG, Bergman IM, Hörnberg G, Zackrisson O, Hellberg E, Östlund L, DeLuca TH. 2007. Radiocarbon dating of prehistoric hearths in alpine northern Sweden: problems and possibilities. Journal of Archaeological Science 34(8):1276-88.

Pessenda LCR, Gouveia SEM, Aravena R. 2001. Radiocarbon dating of total soil organic matter and humin fraction and its comparison with ${ }^{14} \mathrm{C}$ ages of fossil charcoal. Radiocarbon 43(2B):595-601.

Pietikäinen J, Kiikkilä O, Fritze H. 2000. Charcoal as a habitat for microbes and its effect on the microbial community of the underlying humus. Oikos 89(2): $231-42$.

Scharpenseel HW, Becker-Heidmann P. 1992. Twentyfive years of radiocarbon dating soils: paradigm of erring and learning. Radiocarbon 34(3):541-9.

Schmidt MWI, Skjemstad JO, Jäger C. 2002. Carbon isotope geochemistry and nanomorphology of soil black carbon: black chernozemic soils in central Europe originate from ancient biomass burning. Global Biogeochemical Cycles 16(4):1123, doi:10.1029/ 2002 GB001939.

Skjemstad JO, Janik LJ, Head MJ, McClure SG. 1993. High-energy ultraviolet photooxidation: a novel technique for studying physically protected organic-matter in clay-sized and silt-sized aggregates. Journal of Soil Science 44(3):485-99. 
Skjemstad JO, Clarke P, Taylor JA, Oades JM, McClure SG. 1996. The chemistry and nature of protected carbon in soil. Australian Journal of Soil Research 34(2): 251-71.

Skjemstad JO, Taylor JA, Smernik RJ. 1999. Estimation of charcoal (char) in soils. Communications in Soil Science and Plant Analysis 30:2283-98.

Topoliantz S, Ponge JF. 2003. Burrowing activity of the geophagous earthworm Pontoscolex corethrurus (Oligochaeta: Glossoscolecidae) in the presence of charcoal. Applied Soil Ecology 23(3):267-71.

Wang X, Peng PA, Ding ZL. 2005. Black carbon records in Chinese Loess Plateau over the last two glacial cycles and implications for paleofires. Palaeogeography, Palaeoclimatology, Palaeoecology 223(1-2):919.

Willis KJ, van Andel TH. 2004. Trees or no trees? The environments of central and eastern Europe during the Last Glaciation. Quaternary Science Reviews 23(2324):2369-87.

Zackrisson O, Nilson MC, Wardle DA. 1996. Key ecological function of charcoal from wildfire in the Boreal forest. Oikos 77(1):10-9. 